\title{
Potato as a Source of Nutrition for Physical Performance
}

\author{
Mitch Kanter ${ }^{1} \cdot$ Chelsea Elkin $^{1}$
}

Published online: 13 February 2019

(C) The Author(s) 2019

\begin{abstract}
Health professionals universally agree on the importance of a balanced diet, and the fallacy of relying on any one or two food groups, as the means of achieving peak physical performance and health. A review of the existing sports nutrition literature indicates that different types of athletes and physically active people may have slightly different nutritional requirements, but the main tenets of sports nutrition have not changed much over the last 25 years. The specific combinations may vary, but carbohydrates, protein, and fluids are vital components of an active individual's diet. Further, most available research supports the notion that optimal physical performance requires carbohydrate - and, specifically, high-quality, nutrient-dense carbohydrate from whole food sources, like potatoes. High- quality carbohydrate sources - foods that offer an array of macro- and micronutrients as well as energy, can help to build a strong nutritional foundation for the level of training, recovery, and adaptation that most physically active people seek to achieve. Low carbohydrate diets will not generally allow athletes to train at the intensity required to attain peak physical performance.
\end{abstract}

\section{Resumen}

Universalmente, los profesionales de la salud están de acuerdo en la importancia de una dieta balanceada, y la falacia de confiar ya sea en uno o dos grupos de alimentos, como los medios para lograr el máximo de comportamiento físico y salud. Una revisión de la literatura existente sobre la nutrición en los deportes indica que diferentes tipos de atletas y de gente físicamente activa pudieran tener ligeramente diferentes requerimientos de nutrición, pero los principales postulados de nutrición en los deportes no han cambiado mucho en los últimos 25 años. Las combinaciones específicas pudieran variar, pero los carbohidratos, las proteínas, y los fluidos, son componentes vitales de una dieta de un individuo activo. Más aun, la mayoría de la investigación disponible respalda la noción que el rendimiento físico óptimo requiere de carbohidratos, y específicamente, de alta calidad, carbohidratos de densidad nutritiva de fuentes totales de alimentos, como las papas. Fuentes de carbohidratos de alta calidad, alimentos que ofrecen un rango de macro y micronutrientes, así como de energía, pueden ayudar a construir un cimiento fuerte nutricional al nivel de entrenamiento, recuperación, y adaptación que la mayoría de la gente físicamente activa busca lograr. Dietas bajas en carbohidratos no le permitirá generalmente a los atletas entrenar en la intensidad requerida para alcanzar el máximo de rendimiento físico.

Keywords High-quality carbohydrates $\cdot$ Potatoes $\cdot$ Performance

\section{Introduction}

With increasing access to sports dietitians, personal trainers, nutrition trackers and online apps, today's athletes (from the

Chelsea Elkin

celkin@foodminds.com

Mitch Kanter

mkanter@foodminds.com

1 Food Minds, 1101 West River Parkway, Minneapolis, MN 55415, USA weekend warrior to the elite, competitive performer) are more in tune with dietary trends and open to modifying their nutritional intake than ever before. Simultaneously, lowcarbohydrate diets continue to become more prevalent in mainstream conversations on nutrition. Limiting carbohydrate consumption (and total calorie intake overall) may make sense for those who are less physically active, but high-activity individuals like athletes still need highquality carbohydrates to enhance muscle glycogen storage and to deliver carbohydrate to muscle and other organs during strenuous exercise (Helge 2017; Maughan and Shirreffs 2011). 
In this environment, the Alliance for Potato Research and Education (APRE) - representing one of the leading natural carbohydrate sources - set out to re-examine nutritional needs for optimal physical performance and how dietary recommendations have changed over the years. Overall, a review of the existing sports nutrition literature indicated that different types of athletes may have varying nutritional requirements, but the main tenets of sports nutrition have not changed much over the last 25 years. The specific combinations may vary, but carbohydrates, protein and fluids are vital components of an active individual's diet, preferably from natural, whole-food sources (Murray and Rosenbloom 2018). When consumed in the right forms and quantities, they build a strong nutritional foundation for the level of training, recovery and adaptation that athletes seek to achieve.

\section{Potatoes: A High-Quality Carbohydrate for a Balanced Diet}

From a broader nutritional standpoint, health professionals generally agree on the importance of a balanced diet and the fallacy of relying on any one or two food groups as the means of achieving peak physical performance and health (Maughan and Shirreffs 2011; Murray and Rosenbloom 2018; Thomas et al. 2016). Carbohydrate-rich foods have a vital role to play, but only high-quality, nutrient dense carbohydrate sources foods that offer an array of macro- and micronutrients as well as energy, can offer the full range of benefits athletes need (Murray and Rosenbloom 2018).

Potatoes were often cited in the literature as a key example of a high-carbohydrate food that provides multiple nutritional benefits. A medium skin-on baked white potato $(148 \mathrm{~g})$ is an excellent source of potassium (23\% DV), vitamin C (24\% DV), and vitamin B6 (23\% DV) and a good source of dietary fiber $(13 \% \mathrm{DV})$ and magnesium $(10 \% \mathrm{DV})$ based on a $2000 \mathrm{kcal} /$ day diet (Anonymous 2012). In the U.S., studies have demonstrated that only $2 \%-3 \%$ of the population achieves an adequate intake of potassium in their usual intake (Anonymous 2011). Among fruits and vegetables, potatoes represent one of the most significant sources of dietary potassium and can provide health benefits from minimizing the risk of hypertension to supporting bone health. Dietary potassium also serves as an electrolyte that helps athletes maintain fluid balance, a key factor during and after strenuous exercise that can help to stave off dehydration (James et al. 2015).

It is also worth noting the plethora of phytonutrients and antioxidants that have been identified in potatoes (Brown et al. 2005; Kawabata et al. 2015; Liu 2013), and the possibility of yet-to-be-discovered phytochemicals that may exist in the potato, further driving the rationale for high quality, whole food sources, as opposed to manufactured sports bars and gels, as key contributors to health and performance for athletes.
The protein quality of potatoes, which carry a biological value between 90 and 100, is greater than most other nonanimal - and even some animal - sources of protein (McGill et al. 2013). It is well-established that high quality protein sources can help to maximize training-induced increases in muscle accretion and strength following various forms of exercise (Philips and van Loon 2011). As a carbohydrate-rich food that also contains high quality protein, potatoes as a postexercise meal has the potential to not only replenish depleted muscle glycogen stores, but to stimulate muscle protein synthesis as well.

\section{Meeting Carbohydrate Needs for High-Intensity Performance}

A foundational principle referenced previously is the essential function of carbohydrates in an athlete's diet. Dietary protein and fat, to a certain extent, may play a more important role in the athlete's diet than previously appreciated (Maughan and Shirreffs 2011; Thomas et al. 2016). However, carbohydrate remains the substrate most efficiently metabolized by the body and the only macronutrient that can be broken down rapidly enough to provide energy during periods of high-intensity training when fast-twitch muscle fibers are primarily relied upon (Hawley and Leckey 2015; Helge 2017; Jeukendrup 2017; Thomas et al. 2016).

The daily carbohydrate needs of a serious athlete can be staggering. A competitive athlete, who may train four hours per day or more, needs to consume as much as $12 \mathrm{~g} / \mathrm{kg}$ body weight/day of carbohydrate. Even athletes who train fewer hours may need to consume carbohydrates in the range of 5-7 g/kg/day to accommodate moderate exercise needs. For a 175-lb. athlete, this can translate to as much as 3800 carbohydrate calories per day (Thomas et al. 2016). Table 1 contains recommendations regarding the carbohydrate needs of athletes performing different levels of exercise. It's almost impossible to satisfy that level of demand without maintaining a diet rich in carbohydrate sources like potatoes, rice, and pasta. When athletes don't eat enough carbohydrate, they can't fully replenish their muscle glycogen stores (Cox et al. 2010) - which could result in performance losses, fatigue, weakness, and possibly illness, among other things.

\section{Carbohydrate Absorption Rate: A Factor in Performance?}

Most sports nutritionists agree that high-carbohydrate foods and beverages that are rapidly absorbed may be best during exercise for avoiding gastrointestinal issues and providing 
Table 1 Recommendations for daily carbohydrate intake for athletes involved in repeated days of strenuous, prolonged physical activity and training

\begin{tabular}{|c|c|c|c|}
\hline Exercise intensity & Description & $\begin{array}{l}\text { Dietary } \\
\text { carbohydrate }\end{array}$ & Comments \\
\hline Low & $\begin{array}{l}\text { Easy activity such as yoga, tai chi, walking, or any } \\
\text { exercise done at a light effort (can easily talk or } \\
\text { sing during the activity) }\end{array}$ & $\begin{array}{l}3-5 \mathrm{~g} / \mathrm{kg} \\
\mathrm{BW} / \mathrm{d}\end{array}$ & $\begin{array}{l}\text { Normal dietary intake is usually sufficient to } \\
\text { restore muscle glycogen content }\end{array}$ \\
\hline Moderate & $\begin{array}{l}\text { One hour or more of activity such as walking, jogging, } \\
\text { swimming, bicycling at a modest effort (can carry } \\
\text { on a conversation without problem, but cannot sing) }\end{array}$ & $\begin{array}{l}6-7 \mathrm{~g} / \mathrm{kg} \\
\mathrm{BW} / \mathrm{d}\end{array}$ & $\begin{array}{l}\text { A diet in which at least } 50 \% \text { of the energy } \\
\text { (calories) comes from carbohydrate food is } \\
\text { usually sufficient to restore muscle glycogen } \\
\text { content }\end{array}$ \\
\hline High & $\begin{array}{l}\text { One hour or more hard exercise such as interval training, } \\
\text { running, swimming, bicycling at a modest effort } \\
\text { (can carry on only very brief conversation) }\end{array}$ & $\begin{array}{l}6-10 \mathrm{~g} / \mathrm{kg} \\
\mathrm{BW} / \mathrm{d}\end{array}$ & $\begin{array}{l}\text { Postexercise carbohydrate/protein intake, with } \\
\text { high-carbohydrate meals and snacks, is needed } \\
\text { to fully restore muscle glycogen within } 24-36 \mathrm{~h}\end{array}$ \\
\hline Very-high & $\begin{array}{l}\text { Very hard exercise for an hour or more or very prolonged } \\
\text { exercise such as internal training, ice hockey, soccer, } \\
\text { basketball, running, swimming, bicycling at an intense } \\
\text { effort (cannot speak during the effort) }\end{array}$ & $\begin{array}{l}8-12 \mathrm{~g} / \mathrm{kg} \\
\mathrm{BW} / \mathrm{d}\end{array}$ & $\begin{array}{l}\text { Postexercise carbohydrate/protein intake, with } \\
\text { high-carbohydrate meals and snacks, is needed } \\
\text { to fully restore muscle glycogen within } 24-36 \mathrm{~h}\end{array}$ \\
\hline
\end{tabular}

Adapted from Thomas et al. (2016) and Burke et al. (2016)

$B W$ body weight

muscles with needed energy (Hawley and Leckey 2015; Jeukendrup 2017). The types of carbohydrates to consume before and after exercise, however, are not that clear-cut. Some have theorized that lower glycemic carbohydrates, those that appear in the bloodstream more slowly and produce a blunted glucose response, may be best prior to exercise. However, few existing studies support this notion. In one study, Little et al. (2010) provided a pre-event meal of lentils ( $\mathrm{GI}=26$ ) or a meal of mashed potatoes, bread, and egg whites $(\mathrm{GI}=76)$ to athletes two hours prior to high-intensity running. Neither meal improved running performance more than the other. In another longer-term pre-event feeding study, Rauch et al. (1995) supplemented the diet of cyclists with rapidly absorbed potato starch for 3 days prior to a 3-h ride, followed by a 60 -min performance ride. The additional carbohydrate provided by the potato starch resulted in $47 \%$ greater preexercise muscle glycogen stores, and improved cycling performance.

After exercise, particularly when rapid glycogen resynthesis is required (such as when doing two-a-day workouts or when heavy training is performed on successive days) experts indicate that consuming about $0.5-0.6 \mathrm{~g} / \mathrm{kg}$ of rapidly absorbed carbohydrates (roughly the equivalent of one medium potato or a cup of rice or pasta) every $30 \mathrm{~min}$ for two to four hours post exercise can promote rapid glycogen resynthesis (Thomas et al. 2016). When timing is not a factor (i.e., the next exercise bout will not occur for $24 \mathrm{~h}$ or more) researchers suggest that glycogen resynthesis is not so much affected by carbohydrate type as it is by the total amount of carbohydrate consumed between exercise bouts (Burke et al. 2016a). In both short term and longer-term recovery conditions, a rapidly absorbed carbohydrate source, like a potato, can serve as an excellent way to get needed carbohydrates back into the body.

\section{Dietary Practices that May Inhibit Performance}

Fad diets are nothing new, for the general population or for athletes seeking to experiment to enhance performance. These days, regimens like the "training-low" concept or other forms of low carbohydrate, ketone-producing diets are being employed by athletes with varying degrees of success.

Training-low involves skipping meals prior to heavy bouts of exercise, depriving the body of needed nutrients and energy, particularly in the form of carbohydrate. The goal is to train muscles to more readily use fat as a substrate, thus conserving glycogen stores and promoting muscle adaptations that can, in theory, lead to greater endurance (Bartlett et al. 2015; Stellingwerff et al. 2006; Thomas et al. 2016). However, few studies exist confirming the benefits of trainlow regimens, while a large volume of literature indicates that it is difficult to train at high intensity while subsisting on a low carbohydrate diet, which in turn can produce decrements in performance (Cox et al. 2010; Hawley and Leckey 2015; Maughan and Shirreffs 2011; Stellingwerff et al. 2006; Thomas et al. 2016).

Low-carbohydrate, ketone-promoting diets have been used by athletes as well in an effort to become more reliant on the body's near-endless supply of stored fat, while conserving the relatively small depots of stored carbohydrate the body possesses (Volek et al. 2015). However, ultimately there is potential for harm in following this type of diet; potential negative effects include impaired cognitive performance and mood, perceptions of fatigue and an inability to focus (Achten et al. 2004). Another concern is increased vulnerability to skeletal muscle damage due to low glycogen stores during training or competition (Gavin et al. 2014). One recent study of world class race walkers who consumed a low carbohydrate, high fat 
diet for three weeks indicated a loss of exercise economy and subsequent decrements in performance gains (Burke et al. 2016b). Additionally, data shows that as athletes dehydrate during exercise, their reliance on carbohydrate for energy increases, further making the case for maintaining adequate carbohydrate stores (Logan-Sprenger et al. 2012, 2015). Once again, the preponderance of the literature indicates that low carbohydrate diets, and ultimately low bodily carbohydrate stores make it difficult to sustain exercise intensity at a level most competitive athlete are accustomed to training (Burke et al. 2016a; Hawley and Leckey 2015; Jeukendrup 2017; Thomas et al. 2016).

\section{Overconsuming Protein Can Lead to Underconsuming Carbohydrates}

Our understanding of the dietary protein needs for physical performance has grown dramatically over the past decade, and most experts now agree that the current Recommended Daily Allowance for protein $(0.8 \mathrm{~g} / \mathrm{kg} /$ day $)$ is insufficient to meet the needs of most physically active people (Phillips and Van Loon 2011). Many athletes seem to have gotten this message; most research suggests the typical athlete consumes protein at a rate of 1.2 to $2 \mathrm{~g} / \mathrm{kg}$ per day (Maughan and Shirreffs 2011), which is probably more in line with their needs. However, this increase in protein intake has the potential to inadvertently lead to sub-optimal carbohydrate intake which, as reiterated a number of times in this manuscript can negatively impact performance. In these instances, carbohydrate-containing foods that also contain high quality protein, like potatoes, can serve as an obvious food-of-choice for the athlete.

\section{What's Next: Further Exploration of Potatoes and Performance}

As our understanding of exercise science evolves, and new research methods and techniques emerge, significant opportunities exist to further examine the role of potatoes and other high-quality carbohydrate sources in an athlete's diet. A range of topics ripe for exploration exists, such as the role potatoes (as a source of carbohydrates, vitamin $\mathrm{C}$, and other nutrients) might play in exercise-induced skeletal muscle damage repair. Other areas of possible exploration include the potential of potatoes as a high-quality protein source for athletes, as well as the impact of potatoes on muscle growth and repair in different demographic groups. The chronic use of potatoes by hypertensive or hyperlipidemic athletes also merits study, as do performance effects of potatoes versus other more commonly used protein sources such as soy or dairy.

While researchers have fertile ground to refine and expand on current knowledge of sports nutrition, the fundamental importance of potatoes and other high-quality carbohydrate sources for high intensity activity cannot be overstated. Most available research supports the notion that optimal physical performance requires carbohydrate - and, specifically, highquality, nutrient-dense carbohydrate from whole food sources, like potatoes.

Open Access This article is distributed under the terms of the Creative Commons Attribution 4.0 International License (http:// creativecommons.org/licenses/by/4.0/), which permits unrestricted use, distribution, and reproduction in any medium, provided you give appropriate credit to the original author(s) and the source, provide a link to the Creative Commons license, and indicate if changes were made.

\section{References}

Achten, J., L. Moseley SL Halson, M.P. Rayson, A. Casey, and A.E. Jeukendrup. 2004. Higher dietary carbohydrate content during intensified running training results in better maintenance of performance and mood state. Journal of Applied Physiology 96: 13311340.

Anonymous. 2011. US Department of Health and Human Services, US Food and Drug Administration. Nutrient content claims for "good source," "high," "more," and "high potency" [21 CFR 101.54]. Revised as of April 1, 2011.

Anonymous. 2012 US Department of Health and Human Services, US Food and Drug Administration. Nutrition facts for raw fruits and vegetables [21 CFR 101, Appendix C].

Bartlett, J.D., J.A. JA Hawley, and J.P. Morton. 2015. Carbohydrate availability and exercise training adaptations: Too much of a good thing? Eur J Sport Sci. 15: 1-10.

Brown, C.R., D. Culley, R. Durst C-P Yang, and R. Wrolstad. 2005. Variation of anthocyanin and carotenoid contents and associated antioxidant values in potato breeding lines. J Amer Soc Hort Sci. 130: $174-180$.

Burke, L.M., M.L. Ross, L.A. Garvican-Lewis, M. Welvaert, I.A. Heikura, S.G. Forbes, J.G. Mirtschin, L.E. Cato, N. Strobel, A.P. Sharma, and J.A. Hawley. 2016a. Low carbohydrate, high fat diet impairs exercise economy and negates the performance benefit from intensified training in elite race walkers. The Journal of Physiology 595: 2785-2807.

Burke, L.M., L.J.G. van Loon, and J.A. Hawley. 2016b. Post-exercise muscle glycogen resynthesis in human. Journal of Applied Physiology 122: 1055-1067.

Cox, R.C., R.J. Snow, and L.M. Burke. 2010. Race-day carbohydrate intakes of elite triathletes contesting Olympic-distance triathlon events. Into J Sport Nutr Exec Metal. 20: 299-306.

Gavin, J.P., S.D. Myers, and M.E. Willems. 2014. Neuromuscular responses to mild-muscle damaging eccentric exercise in a low glycogen state. Journal of Electromyography and Kinesiology 25: 53-60.

Hawley, J.A., and J.J. Leckey. 2015. Carbohydrate dependence during prolonged, intense endurance exercise. Sports Medicine 45 (Suppl 1): S5-S12.

Helge, J. 2017. A high carbohydrate diet remains the evidence-based choice for elite athletes to optimise performance. The Journal of Physiology 595: 2775.

James, L.J., S.A. Mears, and S.M. Shirreffs. 2015. Electrolyte supplementation during severe energy restriction increases exercise capacity in the heat. European Journal of Applied Physiology 115: 2621-2629. 
Jeukendrup, A.E. 2017. Periodized nutrition for athletes. Sports Medicine 47 (Suppl 1): 51-63.

Kawabata, K., R. Mukai, and A. Ishisaka. 2015. Quercetin and related polyphenols: New insights and implications for their bioactivity and bioavailability. Food \& Function 6: 1399-1417.

Little, J.P., P.D. Chilibeck, and D. Ciona. 2010. Effect of low- and highglycemic-index meals on metabolism and performance during highintensity, intermittent exercise. International Journal of Sport Nutrition and Exercise Metabolism 20: 447-456.

Liu, R.H. 2013. Health-promoting components of fruits and vegetables in the diet. Advances in Nutrition 4: 384S-392S.

Logan-Sprenger, H.M., G.J.F. Heigenhauser, K.J. Killian, and L.L. Spriet. 2012. The effects of dehydration during cycling on skeletal muscle metabolism in females. Medicine and Science in Sports and Exercise 44: 1949-1957.

Logan-Sprenger, H., G. Jones, G.J.F. Heigenhauser, G.L. Jones, and L.L. Spriet. 2015. The effect of dehydration on muscle metabolism and time trial performance during prolonged cycling in males. Physiol Rep. 3: e12483.

Maughan, R.J., and S.M. Shirreffs. 2011. IOC consensus conference on nutrition in sport, 25-27 October 2010, International Olympic Committee, Lausanne, Switzerland. Journal of Sports Sciences 29 (suppl. 1): S3-S4.
Maughan RJ and Shirreffs SM. 2011. Nutrition for sports performance: issues and opportunities. The Proceedings of the Nutrition Society. October 17, 2011.

McGill, C.R., A.C. Kurilich, and J. Davignon. 2013. The role of potatoes and potato components in cardiometabolic health: A review. Annals of Medicine 45: 467-473.

Murray B and Rosenbloom C. 2018. Fundamentals of glycogen metabolism for coaches and athletes. Nutrition Reviews. February 10, 2018.

Phillips, S.M., and L.J. Van Loon. 2011. Dietary protein for athletes: From requirements to optimum adaptation. Journal of Sports Sciences 29 (Suppl 1): S29-S38.

Rauch, L.H.G., I. Rodger, G.R. Wilson, J.D. Bolonje, S.C. Dennis, T.D. Noakes, and J.A. Hawley. 1995. The effects of carbohydrate loading on muscle glycogen and cycling performance. Int J Sports Nutr. 5: 25-36.

Stellingwerff, T., L.L. Spriet, M.J. Watt, M. Hargreaves NE Kimber, J.A. Hawley, and L.M. Burke. 2006. Decreased PDH activation and glycogenolysis during exercise following fat adaptation with carbohydrate restoration. The American Journal of Physiology 290: E380-E388.

Thomas, D.T., K.A. KA Erdman, and L.M. Burke. 2016. American College of Sports Nutrition Joint Position Statement: Nutrition and athletic performance. Medicine and Science in Sports and Exercise 48: 543-568.

Volek, J.S., T. Noakes, and S.D. Piney. 2015. Rethinking fat as a fuel for endurance exercise. Eur J Sports Sci. 15: 13-20. 